\title{
Environmental protection problems in the areas of former mines with emphasis on sinkholes: selected examples
}

\author{
P. Strzałkowski ${ }^{1}$ (D) P. Litwa ${ }^{2}$
}

Received: 2 May 2020 / Revised: 3 July 2020 / Accepted: 18 July 2020 / Published online: 29 July 2020

(c) The Author(s) 2020

\begin{abstract}
The paper concerns an analysis of causes of sinkholes in the area of the former mines located in the Upper Silesia (Poland). The conducted statistical analysis allowed to determine the share of some types of shallow excavations in the formation of sinkholes. Analyses covered the period from 1966 to 2003 and records of more than 300 sinkholes. The research team determined-on the basis of the considerations- that the factor that poses the greatest threat and contributes to the formation of sinkholes during the operation of the mine is shallow goafs. Other such factors are dog headings that have not been decommissioned yet. It can be assumed that they will also generate a significant number of collapses in mines that are no longer in operation. The transition into the state of cave-in of old and shallow dog headings is often caused by loss of loadbearing capacity of a wooden roof support which biodegrades. Collapses linked to these excavations may be predicted with the use of tools such as the method presented in the paper.
\end{abstract}

Keywords Mining subsidence engineering $\cdot$ Mining impact on environment $\cdot$ Post-mining area $\cdot$ Sinkhole

\section{Introduction}

The European underground mining industry of the twentieth century is to a large extent a hard coal industry, which was deactivated due to the depletion of resources, as well as abandonment of coal-based power generation. This happened in Germany, France and the UK. In Poland, although still about $77 \%$ of electricity is produced by burning hard coal and lignite, the volume of extraction and the number of mines have decreased. This may be caused by the reform of the mining industry as well as the depletion of resources and activities aimed at environmental protection. According to the data provided by Statistics Poland, in 1988 there were 70 hard coal mines in Poland with a total annual output of

Editorial responsibility: M. Abbaspour.

P. Strzałkowski

piotr.strzalkowski@polsl.pl

1 Faculty of Mining, Safety Engineering and Industrial Automation, Silesian University of Technology, Akademicka 2, 44-100 Gliwice, Poland

2 GIG Research Institute, Pl. Gwarków 1, 40-166 Katowice, Poland
175 million $\mathrm{Mg}$, and in 2018 there were only 20 mines with total annual output of 63 million $\mathrm{Mg}$.

In the "Report on the activities of Mining Authorities in 2019" (https://www.wug.gov.pl/o_nas/sprawozdania_z_dzial alnosci), it is stated that as at 31 December 2019, there were 20 underground hard coal mines in Poland, which were operating in 30 facilities. In addition, 14 hard coal mines within Spółka Restrukturyzacji Kopalń S.A. ([S.A.—-(polish) Joint Stock Company] were under decommissioning.

In the case of the Ruhr district in Germany, there were 170 closed mines, and their annual output in years of normal operation amounted to 150 million. $\mathrm{Mg}$. These mines employed about 600,000 people (Kretschmann et al. 2017). This obviously led to a vast social problem, but it was also related to environmental protection. As stated in the abovementioned work, environmental hazards resulted from the following reasons: necessity of proper closure of shafts, occurrence of continuous and discontinuous deformations, emission of gas in mines to the atmosphere, slag heaps occupying the area and potential pollution of the atmosphere or changes in water ratios.

Similar observations can be found in the French literature. In the case of the Lorraine iron ore mining industry (Didier 2009), the factors mentioned in the previously described work are related to the environmental impact of 
the decommissioned mines, especially the changes in the ratio of water in the mining industry after the closure of the mines. These changes resulted in an increase in the water level in the rock mass, flooding in the in the city of Auboue and the occurrence of collapses, resulting in construction disasters.

In France, there are some measures that have been undertaken to deal with the problems of environmental risks in the post-mining areas, among other things, the development of a manual for users of these areas, commissioned by the Ministry of Ecology (Salmon et al. 2018).

In order to secure the excavations of the mines adjacent to the decommissioned mines, it is necessary to maintain the shaft of the inactive mines and to continue the dewatering of the rockmass as it is currently carried out in Coal Mine Gliwice located within the Upper Silesian Coal Basin (USCB) in Poland. However, the maintenance of the shafts for the purpose of dewatering of the rockmass results in the release of gas from the shaft, mainly $\mathrm{CO}_{2}$ (Wrona et al. 2016) in a maximum amount of $83 \mathrm{~m}^{3} / \mathrm{h}$. At a distance of $40 \mathrm{~m}$ from the shaft, the concentration of this gas is already at a level similar to the parameters observed in other further areas. This problem was also highlighted in the work (Lagny 2014) relating to the French basin. The work shows the necessity to tightly close excavations with connections with the surface (shafts, drifts, dip headings). Securing the inlet to drifts and dip headings with grating in order to prevent their penetration by unauthorized persons creates favourable conditions for release of gases. In some cases, the amount of $\mathrm{CO}_{2}$ released from the excavations may increase due to chemical reactions between acidic mine waters and carbonate rocks (Awuah-Offei et al. 2016).

The most problematic geotechnical hazards are the occurrence of discontinuous surface deformations (sinkholes) (Genis et al. 2018; Singh and Dhar 1997) and linear deformations (Ścigała and Szafulera 2019; Orwat 2020) and continuous deformations (residual reductions) (Blachowski et al. 2009). Particularly dangerous are sinkholes formed as a result of the transition of the shaft into the cave-in state, which is caused by incorrect closure operation. This problem occurred on a large scale in the UK (Bell 1988), and the hazard was increased by the frequent lack of documentation showing the location of the shafts, which made it necessary to conduct geophysical surveys, openings and drillings.

The environmental impact of the mining activity includes a wide range of factors (Peng 2008; Bell et al. 2000; Bell and Donnelly 2006; Chudek 2010; Knothe 1984; Kratzsch 1983; Whittaker and Reddish 1989), and it refers not only to the activities conducted during operation, but also after the closure of the mines (Hunter 2015). In terms of the factors of a geotechnical nature influencing the environment that pose a threat to the safety of the general public, a particular focus should be directed to the formation of sinkholes as a result of the transition into the cave-in state of the shafts at small depths (Strzałkowski 2018, 2019) incorrectly decommissioned.

This paper presents the general characteristics of the sinkholes which occurred in one of the closed mines within the USCB and undertakes to apply a new proposal of forecasting the sinkholes formed as a result of the transition into the state of cave-in of shallow dog headings (Strzałkowski 2018, 2019). The authors performed the research on their own at the beginning of 2020, having the documentation provided by one of the mines of Upper Silesian Coal Basin.

\section{Materials and methods}

\section{Characteristics of the research area}

\section{General information about the mine}

The research covered a mining area of one of the older mines, currently closed, located in the eastern part of the USCB. The location of the basin on the map of Poland is shown in Fig. 1. The mine was established in 1920, but mining activity had been carried out earlier, as presented in point 2.4. The exploitation of the hard coal deposit was completed as of 31 July 2000 . The decommissioning works included measures such as complete filling of shafts, shaft bottoms and dip headings with rock material, furnace slag, power plant ash and rubble, leaving the possibility of conducting drainage of the rock mass due to the need to secure active neighbouring mines (Pilecki 2012).

\section{Lithology and stratigraphy}

The rock mass in the discussed area was composed of overburden layers consisting of a quaternary and a Triassic formation deposited in the north-eastern part of the area. The Quaternary consists of layers of sand, gravel and clay. The thickness of these layers in the central and southern part is between 2 and $10 \mathrm{~m}$, and in the northern part, it increases to about $20 \mathrm{~m}$. The Triassic formations are located in the north-eastern and eastern part. They were formed as shell limestone and fine sandstone. Their thickness reaches in some places up to $185 \mathrm{~m}$. Under the overburden, there is a Carboniferous formation composed of Łaziska, Orzesze, Ruda and saddle layers. Łaziska layers were formed in the form of sandstone, conglomerate and clay together with coal seams, of which only seam 214 was exploited. Orzesze layers were formed as alternating sandstones and clays. The research included the following deposits: 301, 302, 303, $304 / 2$ and 324/1. Ruda layers form also alternating sandstones and clays together with coal seams No. 401-418. 
Fig. 1 Location of the Upper Silesian Coal Basin

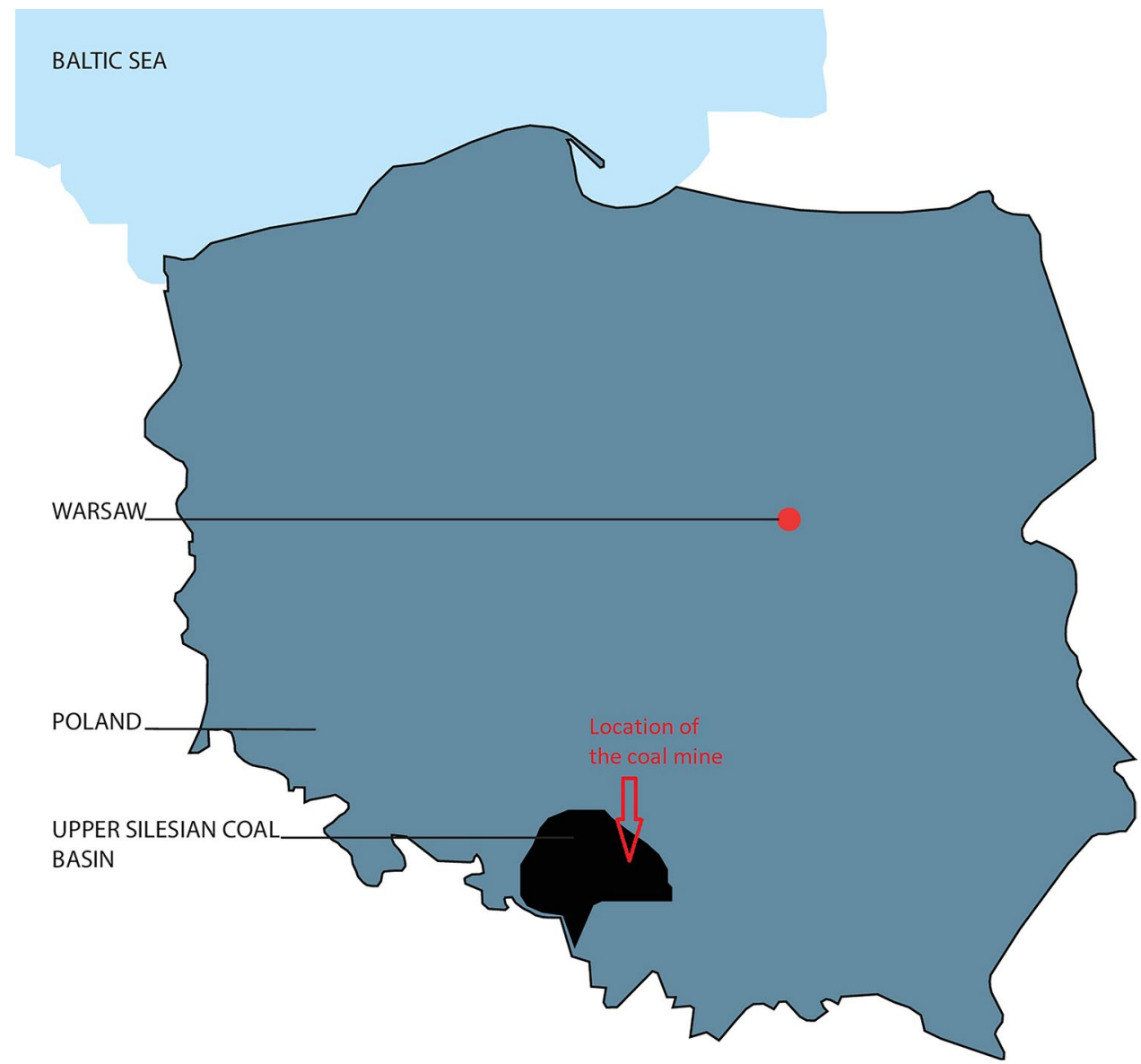

Saddle layers were developed in the sandstone fraction only with the seam 510 .

The lithological profile of the selected formation is presented further when discussing the issue of discontinuous deformations.

\section{Tectonics}

The deposit was cut with numerous faults. The faults with the largest drops have a direction similar to W-E. In the eastern part, there is a fault J-B with a drop height of $h=300 \mathrm{~m}$, branching in the north-eastern part into two faults: $\mathrm{J}$ with a drop height of $h=100 \mathrm{~m}$ and B with a drop height of $h=90 \mathrm{~m}$. These faults drop layers to the west and southwest. In the western part, there is a fault $\mathrm{P}$, which drops the layers to the west to a height of $h=140 \mathrm{~m}$.

\section{Completed mining activity}

In the mining area, the exploitation of calamine ( $\mathrm{Zn}$ ore) was carried out in the nineteenth century. Then, from 1805 onwards, hard coal was exploited, initially using the opencast method and, as the resources deposited, the shallowest were depleted, using the underground method. It should also be noted that in the period before World War II illegal exploitation was carried out, deepening the system of shallow fore-shafts. They were often badly developed and not decommissioned, resulting in a high risk of cavings and sinkholes. They pose even greater hazard as the location of these excavations was not marked on maps. For the purpose of the planned underground exploitation, the deposit was opened by means of dip headings and shaft. The operation was carried out in the seams of the 200 and 300 group using a shortwall and longwall system, both with cave-in and with backfilling. It can be stated that there were three mines in the subject area: a calamine mine, a very shallow coal mine and a mine from the period after 1920, often carrying out works at small depths.

\section{Observed sinkholes}

The sinkholes in the subject area were recorded from 1966 to 2003. Therefore, they covered the period of the decommissioned mines operating before the establishment of the modern mine, as well as related to the activities of the new facility. Six sinkholes were formed after the complete closure of the mine above dog headings. Analysing the causes 
Table 1 Number of sinkholes recorded between 1966 and 2003

\begin{tabular}{llcc}
\hline Item & Reason & $\begin{array}{l}\text { Number } \\
\text { of sink- } \\
\text { holes }\end{array}$ & Percent \% \\
\hline $1 \quad$ Cave-in of the excavation & 232 & 68 \\
$2 \quad$ & $\begin{array}{l}\text { Cave-in of the gallery without an } \\
\text { outlet to the surface }\end{array}$ & 60 & 18 \\
$3 \quad$ & $\begin{array}{l}\text { Cave-in of a shaft of shallow fore- } \\
\text { shaft }\end{array}$ & 24 & 7 \\
4 & $\begin{array}{l}\text { Cave-in of a dip-heading } \\
5\end{array} \quad$ Nonmining causes & 10 & 3 \\
Total & & 13 & 4 \\
\hline
\end{tabular}

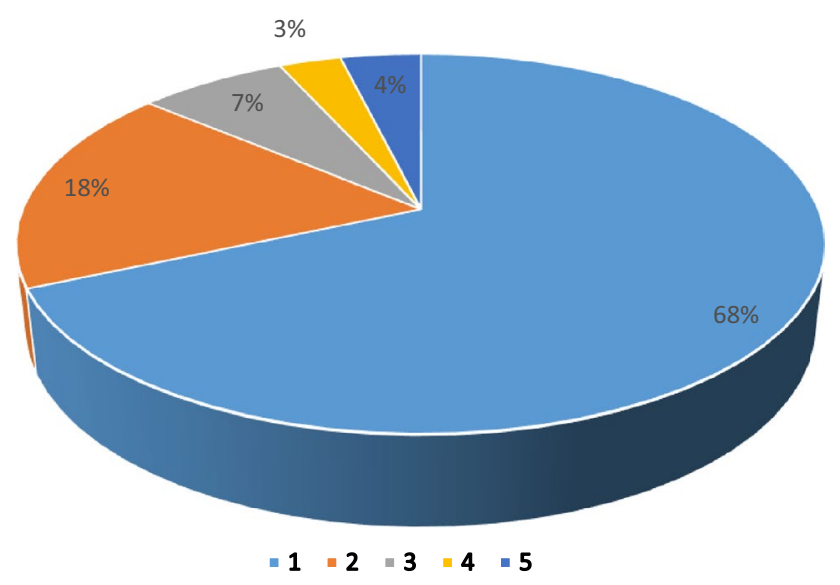

Fig. 2 Percentage share of sinkholes with a division of their causes of the sinkholes, it can be concluded that they were related to:

- Voids in the goafs.

- The transition into the state of cave-in of underground excavations.

- The transition into the state of cave-in of shafts and illegally created shallow fore-shafts.

- The transition into the state of cave-in of excavations drilled from the surface.

- Causes not linked to the mining activity, mainly due to suffosion on the outcrops of tectonic faults on the carboniferous roof.

Data on the number of sinkholes are presented together with their causes in Table 1 and graphically illustrated in Fig. 2.

Figure 3 shows a histogram made in the Statistica, showing the number of sinkholes which occurred over dog headings and excavations depending on the depth of their location. The sinkholes corresponding to the following positions are therefore included: 1, 2, 4 of Table 1, in total 302 .

The figure shows the approximation of the histogram with an exponential function. The majority of the sinkholes were associated with voids located at depths of up to $20 \mathrm{~m}$. Generally, the number of sinkholes decreased as the depth increased, which is natural. However, a new conclusion may be that the occurrence of sinkholes may be confirmed as a result of the transition into the state of cave-in of excavations located at depths exceeding $100 \mathrm{~m}$. Such sinkholes were recorded only five times out of the total number 302. Figure 4 shows the numbers of observed deformations (sinkholes) which were caused by the transition into the state of cave-in of voids with depths from
Fig. 3 A histogram showing the division of the sinkholes depending on the range of the excavation depths above which they were formed

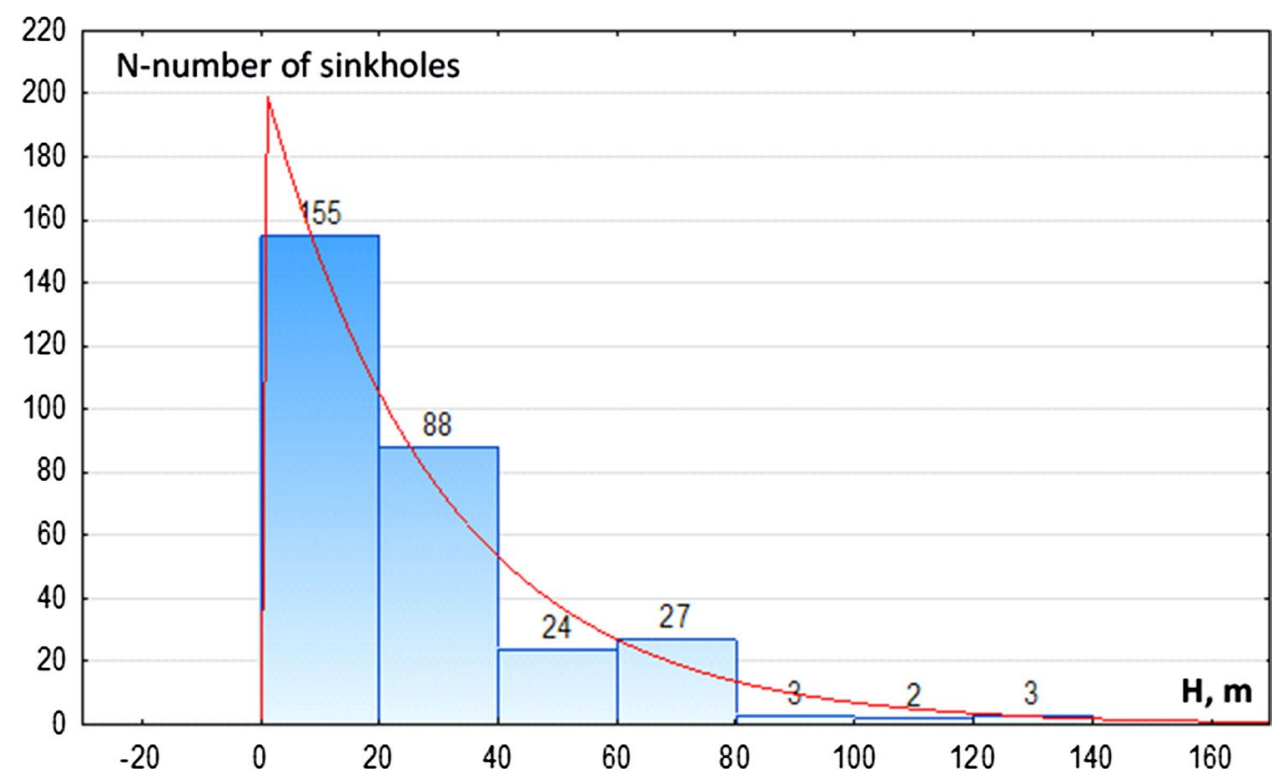


Fig. 4 Relationship between the number of sinkholes and the depth of voids (for the interval of $20 \mathrm{~m}$ )

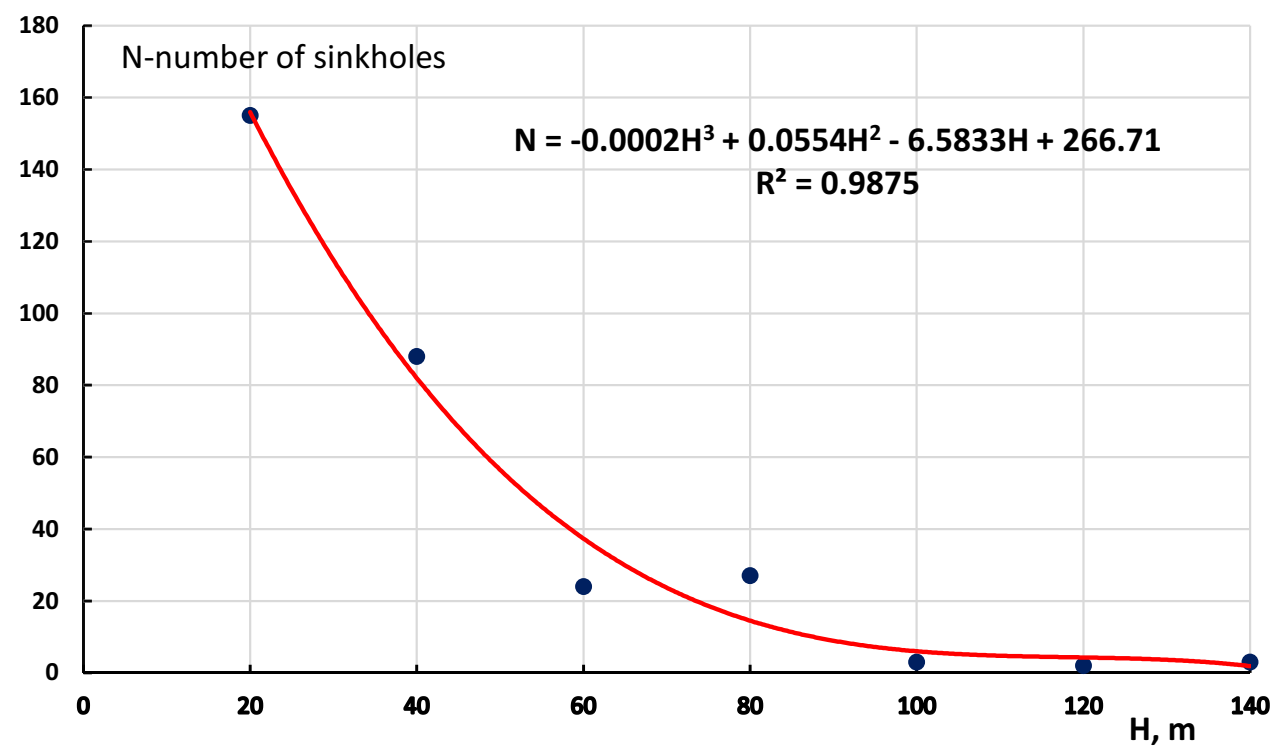

individual range every $20 \mathrm{~m}$. As can be seen with great accuracy, the variability is approximated by polynomial 3 degree $\left(R^{2}=0.99\right)$.

The following data should be taken into account when analysing the results obtained. The largest number of sinkholes was formed over the excavations (68\%), then over the dog headings (21\%) and as a result of the transition into the state of cave-in of shafts (7\%). The mining excavations occupy the largest area of all excavations. In the case of cave-in mining, there are always some voids left in the drifts, which are clenched by subsequent operations or by tremors and rock bursts (Zorychta and Litwa, 2003; Litwa and Król 2010). However, it is difficult to predict whether and where such voids may occur. Moreover, in the absence of activating factors, i.e. in closed mines, the generated balance in the rock mass should be maintained, so it is difficult to expect the occurrence of collapses. The sinkholes should be associated with the phenomenon of suffosion. The situation is different in the case of dog headings. In the ninetieth and at the beginning of the twentieth century, usually no measures were taken to properly decommission such excavations-the wooden supports were not removed. As a result of the destructive factors, the wood was damaged, and thus the bearing capacity of the support decreased, which led to the formation of the cave-in and subsequent formation of a sinkhole on the surface. Therefore, it should be assumed that in the case of closed mines, the factors that contribute to the formation of sinkholes on the surface may be the loss of stability of shallow dog headings, especially in wooden support, which easily biodegrade. In view of the above observations, it is advisable to predict collapses in cases of loss of stability of old, shallowly located dog headings. Such analyses are presented below.

\section{The methodology used in the paper}

The transition into the state of cave-in of a void of both natural origin and agricultural origin may result in the formation of surface sinkholes (Augarde et al. 2003; Chudek et al. 1988). The formation of sinkholes poses a significant threat to the community and the buildings on the surface. It is therefore no surprise that there are a number of methods for forecasting the collapse. Some of them are based on analytical methods (Chudek et al. 1988); others use numerical methods (Genis et al. 2018).

This work is based on two methods applied to predict sinkholes due to the loss of stability of a shallow void. The first is a deterministic method developed by P. Strzałkowski (Strzałkowski 2015) based on the theory of pressure arches by Sałustowicz (1965). The second method is the method allowing to determine the probability of a collapse developed by Chudek and Olaszowski (Chudek et al. 1988).

Method based on the theory of the pressure arch

The method is developed by Strzałkowski (Strzałkowski $2015,2018,2019)$ and uses the Sałustowicz's theory of the pressure arch. According to Sałustowicz's theory, the pressure arch is created only when $\sigma_{x \max } \geq R_{r}$, where $\sigma_{x}$ is the stress in the roof of the void in the direction of $x, R_{\mathrm{r}}$ is the rock tensile strength.

The vertical cross-section area of the part of the required $P_{\mathrm{e}}$ loosened zone (see Fig. 5) equals:

$P_{e}=S_{1}-\frac{w l}{2}+2 \cdot S_{2}$

where $S_{1}$ is the cross-section area of the upper part of the fracture ellipse (the loosened zone) 


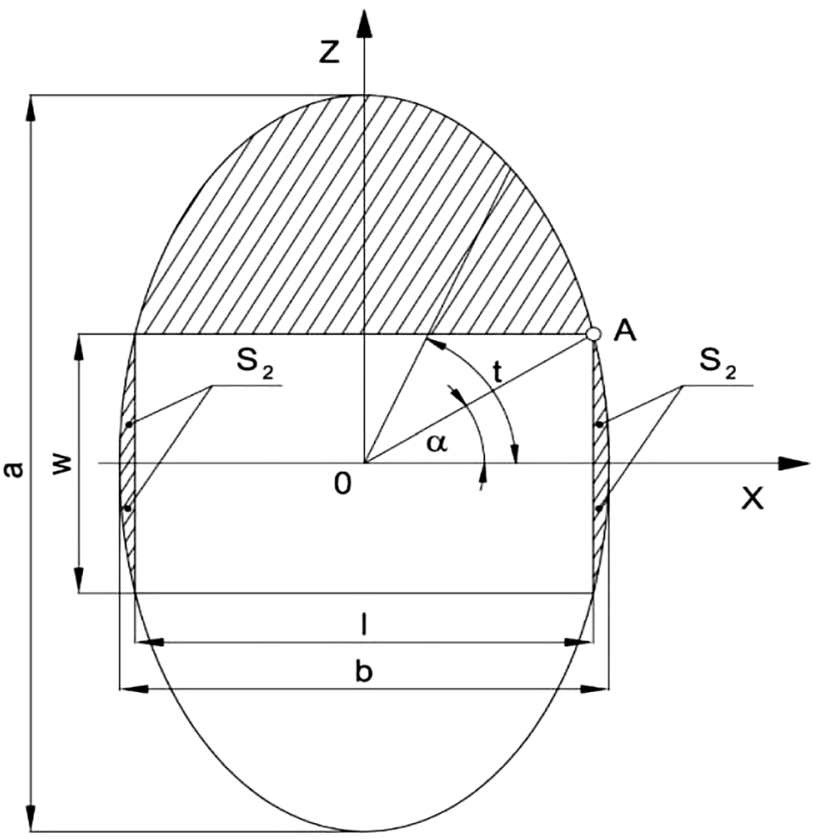

Fig. 5 Loosened zone around the void (working) in the rock mass (Strzałkowski 2015)

$S_{1}=\frac{\pi a b}{8}$

$w, l$ are height and width of the excavation $a, b$ are axes of the stress-relieved zone ellipse

$S_{2}=\frac{1}{2} \int_{0}^{k}\left[\frac{b}{2} \cos t \cdot \frac{a}{2} \cos t-\frac{a}{2} \sin t \cdot \frac{b}{2}(-\sin t)\right] d t-\frac{w l}{8}=\frac{a b k-w l}{8}$

$k=\pi \alpha / 180^{\circ}$ $k=\frac{\pi}{180^{\circ}} \cdot \arctan \frac{w}{l}$

Therefore,

$P_{e}=\frac{a b(\pi+2 k)-6 w l}{8}$

According to the method (Strzałkowski 2015), when a collapse occurs, rocks of the loosened zone move in the direction of the void and fill the working. Assume that:

$P_{1}=P_{e} \cdot k_{r}$

$P_{2}=P_{e}+w \cdot l$

where $k_{r}$ is rock loosening coefficient, being a relation between the volume of crushed rock and the rock lump before crushing.

Two cases may be distinguished:

- when $P_{1}=P_{2}$, the void backfills completely with the rocks from the loosened zone as shown in Fig. 6a;

- when $P_{1}<P_{2}$, a secondary void forms in the top part of the loosened zone. Its volume equals the subtraction of the values of the surface areas $P_{2}-P_{1}$ (Fig. 6b). A sinkhole is formed when the loosened zone related to the secondary void reaches the overburden layer.

- rocks included originally in relaxed zone, after fragmentation, tightly fill drift (void) and relaxed zone,

- after filling of void with fragmented rock from relaxed zone, secondary void forms in the vicinity of top part of ellipse.

The Chudek-Olaszowski method

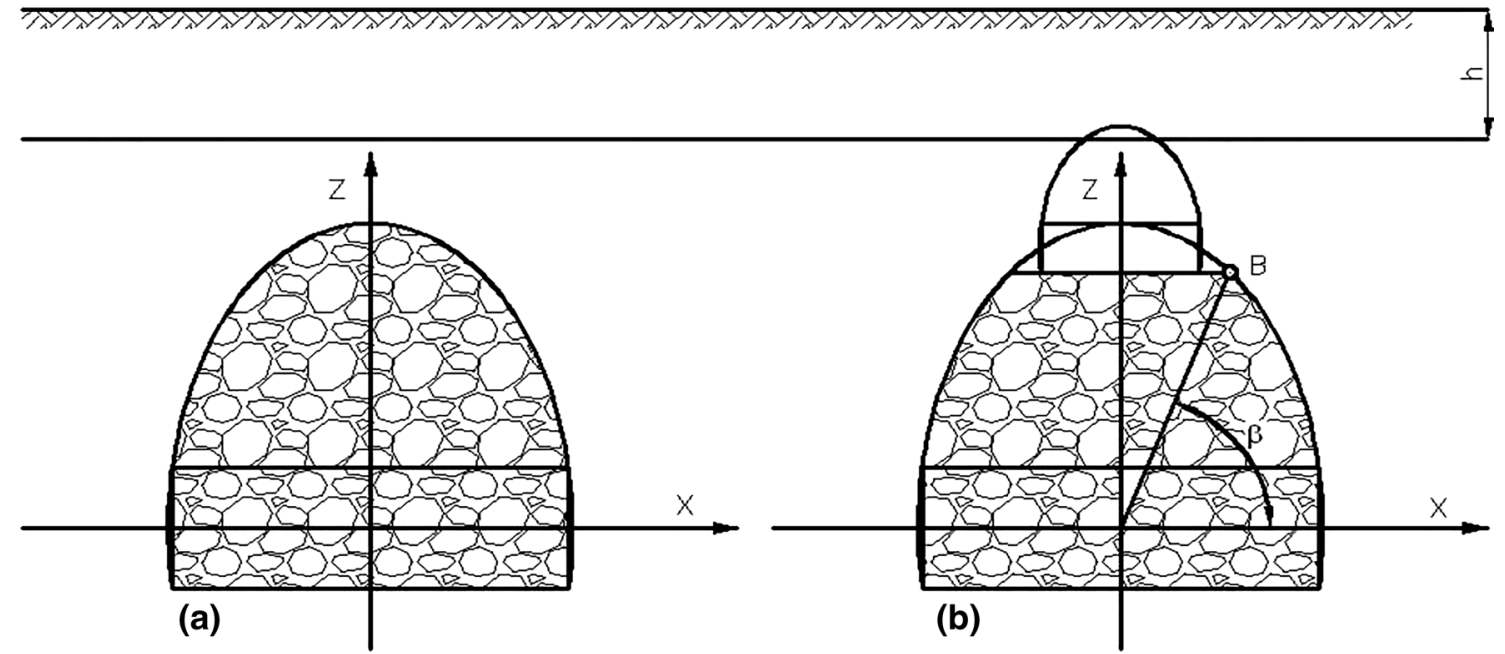

Fig. 6 Possibility of forming of caving zone in the vicinity of void (Strzałkowski 2015) 
The paper uses the above method in the version allowing to calculate the value of the probability of a sinkhole formation on the surface. First, the value of $Z$ indicator should be calculated.

The formula for calculation of $\mathrm{Z}$ indicator is expressed as follows (Chudek et al. 1988):

$z=\frac{H-h}{g}$

where $H$ is depth of the void's roof, $\mathrm{m} h$ is thickness of the overburden, $\mathrm{m}, g$ is height of the void, $\mathrm{m}$.

It is then assumed that the value of the $Z$ indicator corresponds to the value of the probability of the occurrence of a sinkhole.

The value of the probability $(\mathbf{P})$ is determined by the following equation:

$P(z)=1.34-0.036 \cdot Z+0.00019 \cdot Z^{2}$

When $Z<10, P=1, Z>50, P=0$, so that the probability value is between 0 and 1 .

\section{Results and discussion}

An elliptical-shaped sinkhole with axes of $0.5 \mathrm{~m}$ and $0.8 \mathrm{~m}$ long and about $1 \mathrm{~m}$ deep was created over a dog heading located at a depth of about $25 \mathrm{~m}$. The excavation site was an old gallery $2.5 \mathrm{~m}$ high and $3.0 \mathrm{~m}$ wide from 1858 made with a wooden support. The profile of the rockmass in the excavation area is shown in Fig. 7. With the geological documentation, it was decided to make a backward forecast of the formation of the sinkhole.

The calculations were made for particular layers of the rock layers which form the rock mass according to the study (Kidybiński 1982), understating the values of rock tensile strength $R_{\mathrm{r}}$ due to the very low depth of the excavation location. The values used in the calculation are listed in Table 2.

Note:

$\gamma$ is volumetric weight of the rocks,

$R_{\mathrm{r}}$ is tensile strength,

$k_{\mathrm{r}}$ is rock loosening coefficient in the cave-in area,

$h_{\mathrm{w}}$ is thickness of the layer.

Appropriate calculations were made in a computer program (Strzałkowski 2018), and the results are presented in Fig. 7. As a result of the calculations, secondary voids were obtained, according to the calculation scheme presented in Fig. 6. Figure 7 presents only every secondary void, because presenting all of them would obscure the picture. The calculations show that a sinkhole is formed on the surface, because the crack zone of the last void on the left reaches a loose overburden.

If the Chudek-Olaszowski method is used for data:

- Depth to gallery's roof $H=22.90 \mathrm{~m}$

- Volume of loose overburden $h=5.00$

- Excavation height $g=2.50 \mathrm{~m}$,

The following is obtained: value of indicator $Z=7.16$, probability of occurrence of the sinkhole $P=1$.

As can be seen from the above, consistent results were obtained using the deterministic method as well as the probability-based method. The presented calculation results clearly indicate the occurrence of a sinkhole.

\section{Conclusion}

In the area of old mines, often already closed down, the problem of the formation of sinkhole greatly impacts on public safety. In the framework of this work, the cases of surface sinkholes in the area of a decommissioned hard coal mine were analysed. The history of mining in this area covered the period from the nineteenth century to the end of the twentieth century. Shallow excavations were linked to extraction of both galvanic and coal. There are many more areas with similar geological and geological in Silesia, Poland. This allows to assume that the area included in the research is representative of the whole region. It should also be emphasized that a certain, although small number of sinkholes were connected with excavations located at a depth of more than $100 \mathrm{~m}$. This depth is assumed to be a borderline which means that it contributes to the formation of sinkholes. The following conclusions were developed on the basis of the results:

1. The conducted statistical analysis indicates that the largest number of sinkholes occurred over shallow mining excavations (68\%). This is undoubtedly linked to the fact that the mining excavations were the largest and covered the largest area of the mine. The location of voids is difficult to determine and requires geophysical research. The voids in the old goafs remain in a state of some balance, which may be affected by further exploitation and seismic phenomena. They therefore pose lower risk in the case of inactive mines, in the area where the sinkholes are most often caused by suffusion.

2. A significant risk is posed by the former dog headings with a wooden support, where usually no measures to decommission the support were undertaken. The number 
Fig. 7 Location of the excavation and the successive voids in the rock mass on the lithological profile. Note: 1 sand, 2 shale, 3 coal seam

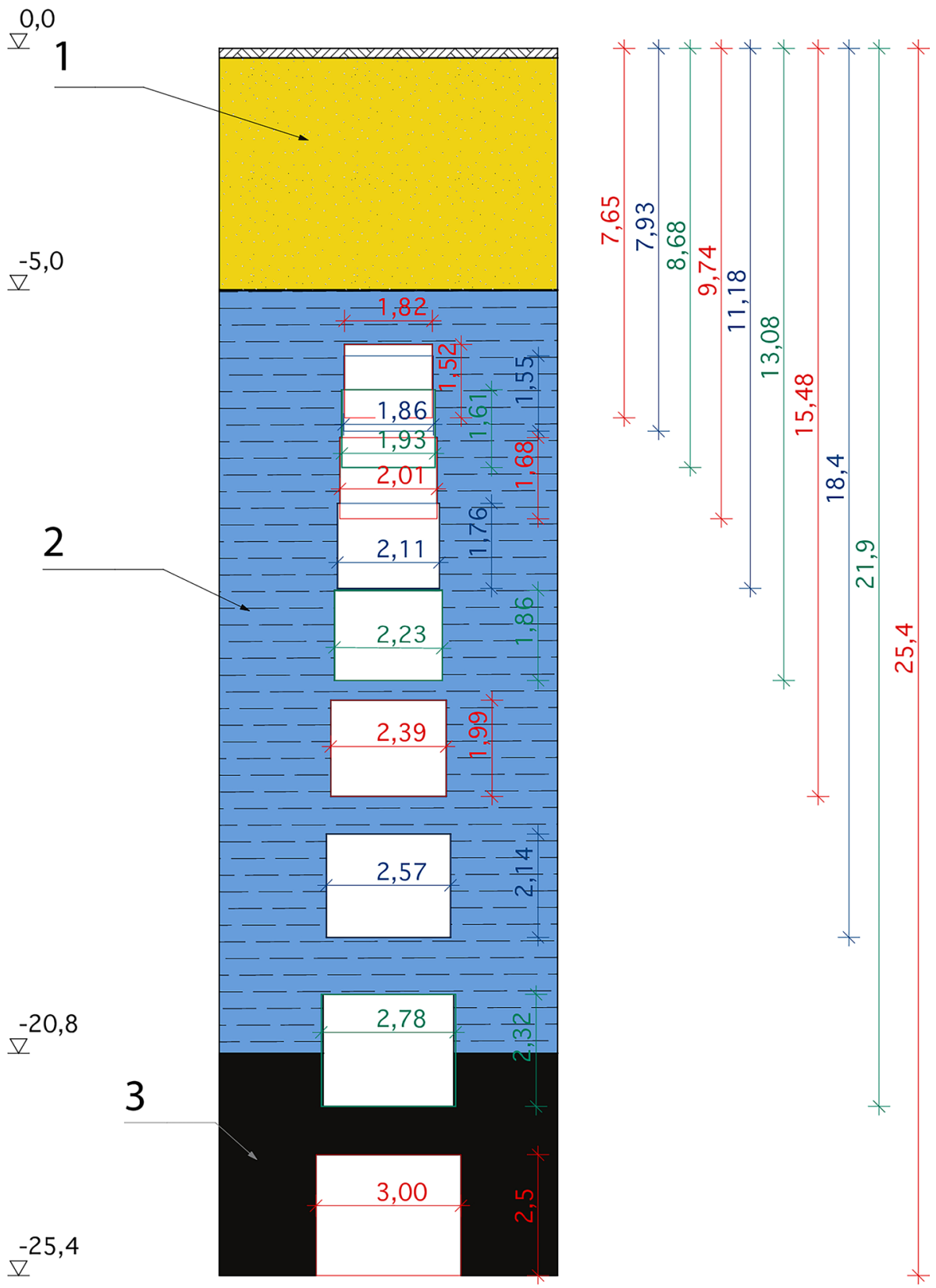

Table 2 List of physical properties of the layers forming rock mass

\begin{tabular}{lllllr}
\hline Layer no & Rock & $\gamma\left(\mathrm{MN} / \mathrm{m}^{3}\right)$ & $R_{\mathrm{r}}(\mathrm{Mpa})$ & $k_{\mathrm{r}}$ & $h_{\mathrm{w}}(\mathrm{m})$ \\
\hline 1 & Sand & 0.027 & 0.00 & 1.0 & 5.00 \\
2 & Shale & 0.025 & 0.10 & 1.1 & 15.80 \\
3 & coal & 0.016 & 0.15 & 1.1 & 4.60 \\
\hline
\end{tabular}

of sinkholes associated with these excavations was $21 \%$. All registered sinkholes after the complete cessation of operations were associated with these drifts. Biodegra- dation of wood causes a decrease in the load-bearing capacity of the support over time, leading to a collapse in the excavation and ultimately to the formation of a sinkhole on the surface. In the case of decommissioned mines, the dog headings should be considered as a factor significantly contributing to formation of sinkholes. Having access to documentation of mining activity supports the predictions of the occurrence of a collapse as it provides dimensions of the voids and their location as well as the construction of the rockmass. Such a forecast can be made with the methods presented in the paper. 
3. Mining shafts from the nineteenth century and the beginning of the twentieth century are always a potential source of sinkholes due to their inappropriate decommissioning. They constituted a relatively small percentage (7\%) of the incidents that generated collapses. However, it should be remembered that they always represent the smallest share of all mine workings. A separate issue is the illegally hollowed-out fore-shafts, poorly secured and not documented on maps of mining activity.

Acknowledgments The authors of the publication would like to express their gratitude to the employees of the Archive of Measuring and Geological Documentation at the Higher Mining Office for their contribution and assistance in making available the archival documentation of the decommissioned mine.

\section{Compliance with ethical standards}

Conflict of interest The authors declare that they have no conflict of interest.

Open Access This article is licensed under a Creative Commons Attribution 4.0 International License, which permits use, sharing, adaptation, distribution and reproduction in any medium or format, as long as you give appropriate credit to the original author(s) and the source, provide a link to the Creative Commons licence, and indicate if changes were made. The images or other third party material in this article are included in the article's Creative Commons licence, unless indicated otherwise in a credit line to the material. If material is not included in the article's Creative Commons licence and your intended use is not permitted by statutory regulation or exceeds the permitted use, you will need to obtain permission directly from the copyright holder. To view a copy of this licence, visit http://creativecommons.org/licenses/by/4.0/.

\section{References}

Awuah-Offei K, Que S, Mathiba M (2016) Delineating hazardous $\mathrm{CO}_{2}$ fluxes from acid mine drainage. Environ Earth Sci 75:239. https ://doi.org/10.1007/s12665-015-5063-6

Augarde CA, Lyamin AV, Sloan SW (2003) Prediction of undrained sinkhole collapse. J Geotech Geoenviron Eng 129(3):197-205. https://doi.org/10.1061/(ASCE)1090-0241

Bell FG, Donnelly LJ (2006) Mining and its impact on the environment. CRC Press, London

Bell FG (1988) Land development. State of the art in location of old mine shafts. Bull Int Assoc Eng Geol 3:91-98. https://doi. org/10.1007/BF02590374
Bell FG, Stacey TR, Genske DD (2000) Mining subsidence and its effect on the environment: some differing examples. Environ Geol 40:135-152. https://doi.org/10.1007/s002540000140

Blachowski J, Cacoń S, Milczarek W (2009) Analysis of post-mining ground deformations caused by underground coal extraction in complicated geological conditions. Acta Geodyn Geomater 6(3):351-357

Chudek M (2010) Mechanika górotworu z podstawami zarządzania ochroną środowiska w obszarach górniczych i pogórniczych. Wydawnictwo Politechniki Śląskiej, Gliwice (in Polish)

Chudek M, Janusz W, Zych J (1988) Studium dotyczące stanu rozpoznania i prognozowania deformacji nieciagłych pod wpływem podziemnej eksploatacji złóż. Zeszyty Naukowe Politechniki Śląskiej, seria Górnictwo, vol. 141, Gliwice (in Polish)

Didier C (2009) Postmining management in France: situation and perspectives. Risk Anal 29(10):1347-1354. https://doi.org/10.111 1/j.1539-6924.2009.01258.xineris-0096194

Genis M, Akcin A, Aydan O, Bacak G (2018) Investigation of possible causes of sinkhole incident at the Zonguldak Coal Basin. Turkey Geomech Eng 16(2):177-185. https://doi.org/10.12989/ gae.2018.16.2.177

Hunter J (2015) Old mines and new sinkholes along the Hucklow Edge vein. Derbyshire Am Geol 18(4):213-226

Kidybiński A (1982) Podstawy geotechniki kopalnianej. Wydawnictwo 'Śląsk', Katowice (in Polish)

Knothe S (1984) Prognozowanie wpływów eksploatacji górniczej, Wydawnictwo 'Śląsk'. Katowice, Poland (in Polish)

Kratzsch H (1983) Mining subsidence engineering. Springer, Berlin

Kretschmann J et al (2017) From mining to post-mining: the sustainable development strategy of the German Hard Coal Mining Industry. IOP Conf Ser Earth Environ Sci 50:012024

Lagny C (2014) The emissions of gases from abandoned mines: role of atmospheric pressure changes and air temperature on the surface. Environ Earth Sci 71:923-929. https://doi.org/10.1007/s1266 5-013-2495-8

Litwa P, Król K (2010) Zwalczanie zagrożeń naturalnych w górnictwie podziemnym - kierunki działania nadzoru górniczego. Wiadomości Górnicze No 9:506-510 (in Polish)

Orwat J (2020) Causes analysis of occurrence of the terrain surface discontinuous deformations of a linear type. J Phys 1426:1-9. https://doi.org/10.1088/1742-6596/1426/1/012016

Peng S (2008) Coal mine ground control, 3rd edn. West Virginia University, Morgantown

Pilecki Z (2012) Zagrożenia deformacjami nieciągłymi na obszarze górniczym Jaworzno III. Wydawnictwo IGSMiE PAN (in Polish).

Salmon R, Franck C, Hadadou R, Lombard A, Thiery S (2018) New guidelines for post mining risks management in France. 12. International conference on mine closure (Mine CLosure 2018), Leipzig, Germany. ineris-0196031

Singh KB, Dhar BB (1997) Sinkhole subsidence due to mining. Geotech Geol Eng 15(4):327-341. https://doi.org/10.1007/BF008 80712

Sałustowicz A (1965) Zarys mechaniki górotworu. WGH, Katowice (in Polish) 
Strzałkowska E (2019) The application of thermal analysis in testing the combustibility of timber used in supporting of mine roadways. Mining of Sustai HYPERLINK "about:blank"nable Development, 28 November 2018, Gliwice, Poland. IOP Conf Ser Earth Environ Sci 261:012049. https://doi.org/10.1088/1755-1315/261/1/012049

Strzałkowski P (2015) Mathematical model of forecasting the formation of sinkhole using Salustowicz's theory. Arch Min Sci 1:63-71

Strzałkowski P (2018) The proposal of predicting formation of sinkholes with an exemplary application. J Mining Sci 1:53-58

Strzałkowski P (2019) Sinkhole formation hazard assessment. Environ Earth Sci, vol. 78. doi: https://doi.org/10.1007/s12665-018-8002-5

Ścigała R, Szafulera K (2019) Linear discontinuous deformations created on the surface as an effect of underground mining and local geological conditions-case study. Bull Eng Geol Environ (in press)

Whittaker BN, Reddish DJ (1989) Subsidence occurrence, prediction and control. developments in geotechnical engineering. Elsevier, Amsterdam

Wrona P, Różański Z, Pach G (2016) Closed coal mine shaft as a source of carbon dioxide emissions. Environ Earth Sci 75:1139. https:// doi.org/10.1007/s12665-016-5977-7

Zorychta A, Litwa P (2003) Geomechaniczne modele górotworu tąpiącego. Biblioteka Szkoły Eksploatacji Podziemnej - Seria z perlikiem nr 7. Kraków. W pracy zbiorowej pod redakcją A. Zorychty:80-90 (in Polish) 